\title{
Economics of in-Season Nitrogen Management Practices for Corn Production
}

\author{
Sami Khanal ${ }^{1 *}$, John Fulton ${ }^{1}$, Ajay Shah ${ }^{1}$, Andrew Klopfenstein ${ }^{1}$, Nathan Douridas ${ }^{2}$ and Scott Shearer ${ }^{1}$ \\ ${ }^{1}$ Department of Food, Agricultural and Biological Engineering, Ohio State University, USA \\ ${ }^{2}$ Farm Science Review, Ohio State University, USA
}

Submission: February 08, 2017; Published: March 27, 2017

*Corresponding author: Sami Khanal, Department of Food, Agricultural and Biological Engineering, Ohio State University, USA, Tel: 330-2633636; Email: Khanal.3@osu.edu

\begin{abstract}
Environmental pollution due to excessive use of nitrogen $(\mathrm{N})$ fertilizer in agricultural production has become a serious issue of concern worldwide. Farmers are under increasing pressure to adopt farming practices that maintain high crop yields as well as reduce environmental footprints. Among options for addressing these challenges is the use of in-season $\mathrm{N}$ management practices that result in good synchronization between $\mathrm{N}$ fertilizer supply and crop demand, thereby reducing the chances of $\mathrm{N}$ loss and improving crop $\mathrm{N}$ use efficiency. The objectives of this study were to

a. Determine the impact of timing and rate of $\mathrm{N}$ application on corn yield; and

b. Compare the economics of in-season $\mathrm{N}$ management practices with the baseline management practice that involves application of large quantities of $\mathrm{N}$ prior to planting and a small portion of $\mathrm{N}$ at planting.

Twenty-four treatments, with combinations of four fertilization times (i.e., pre-planting, at-planting, mid-season, and late-season) and three at-planting $\mathrm{N}$ rates $\left(11,45\right.$, and $\left.78 \mathrm{~kg} \mathrm{~N} \mathrm{ha}^{-1}\right)$, were evaluated. Economic return from each treatment was estimated by accounting for the uncertainties associated with crop yield from the treatments, prices for corn yield and costs of fertilizer and its application, and compared with the baseline management practice. For the treatments that received zero $\mathrm{N}$ prior to planting but in-season $\mathrm{N}$ application (i.e., side dressing and late season), corn yield increased significantly with the increase in $\mathrm{N}$ application rate at planting. However, in the treatments that received $\mathrm{N}$ prior to planting, corn yield did not increase significantly with higher $\mathrm{N}$ application at planting. In the treatment that received only $11 \mathrm{~kg} \mathrm{~N} / \mathrm{ha}$ at planting, the mean economic return was negative (i.e., $\$ 17 / \mathrm{ha}$ ). In the treatment that received side-dressing and late-season $\mathrm{N}$ but no $\mathrm{N}$ prior to planting, the economic return was $\$ 47 /$ ha higher than the baseline $\mathrm{N}$ management practice. With a higher $\mathrm{N}$ application rate at planting (i.e., $78 \mathrm{~kg} \mathrm{~N} / \mathrm{ha}$ ), in-season $\mathrm{N}$ applications yielded higher economic returns in the treatments that received no $\mathrm{N}$ prior to planting than those receiving $\mathrm{N}$ prior to planting. This study suggested that $\mathrm{N}$ is a limiting factor for corn yield but also that in-season $\mathrm{N}$ application helps minimize losses in crop yield and can generate higher economic return.
\end{abstract}

Keywords: Corn yield; Nitrogen fertilization; Timing; In-season

\section{Introduction}

Nitrogen $(\mathrm{N})$ is the critical nutrient for maximizing yield and profitability of corn production. As a result, farmers have historically applied more $\mathrm{N}$ than required by corn, regardless of the soil, environmental and climatic conditions. This excess $\mathrm{N}$ is lost from agricultural fields via runoff, leaching and volatilization and thus has been a major contributing factor to poor water quality around the world, including eutrophication in Lake Erie, the Gulf of Mexico and the Baltic Sea [1-3]. Increasing fertilizer prices [4] and environmental impacts due to excessive use of $\mathrm{N}$ fertilizer have heightened the needs for efficient $\mathrm{N}$ management practices that are both profitable and environmentally sustainable [5].
Rate and timing of $\mathrm{N}$ application are the critical management factors influencing $\mathrm{N}$ use efficiency (NUE) and economic profitability of corn production. Applying more $\mathrm{N}$ than needed by crops early in the growing season to maximize yield usually results in greater $\mathrm{N}$ loss and lower net return. With the current $\mathrm{N}$ management practices that focus on application of a large fraction of $\mathrm{N}$ prior to planting, there is a poor synchrony between soil $\mathrm{N}$ supply and crop demand. Application of large amounts of pre-plant $\mathrm{N}$ results in high levels of inorganic $\mathrm{N}$ in the soil profile that can be lost by leaching or runoff or denitrification before rapid crop uptake occurs. In the United States, of the total $\mathrm{N}$ fertilizer applied to corn, it has been estimated that $75 \%$ is 
applied in the fall or spring before the corn is planted and $25 \%$ is applied after planting [6].

Among options to enhance synchronization between $\mathrm{N}$ fertilizer supply and crop need is the use of in-season $\mathrm{N}$ application in which some portion of total $\mathrm{N}$ is applied prior to or at planting and the rest is side-dressed prior to tasseling. Because a greater portion of the $\mathrm{N}$ is applied when the plant is already established and in the rapid uptake growth phase, this approach results in good synchronization between $\mathrm{N}$ fertilizer supply and crop demand. Also, delaying application of some or all $\mathrm{N}$ fertilizer until after planting may allow for proper diagnosis of crop N needs, by either in-season soil testing or sensing crop color [7]. Although it is well established that important and large $\mathrm{N}$ accumulation occurs during mid-to-late vegetative growth [6], studies have reported mixed effects of in-season $\mathrm{N}$ application practices on corn yield. A study by [7] found little or no yield loss when in-season $\mathrm{N}$ application was delayed to the V11 growth stage and only a 3\% yield loss when delayed until V12 to V16. Contrary to this finding, [8] observed significant declines in corn yields with increasing delay in in-season $\mathrm{N}$ application. Some of the limitations to in-season $\mathrm{N}$ applications include the potential of a dry surface where applied $\mathrm{N}$ may not be accessible for plant uptake, limited field access during wet periods, and the need for high clearance equipment that can move through tall corn [9]. These issues not only introduce additional costs to farmers but also uncertainties in crop grain yield and economic returns.

To consider whether or not in-season $\mathrm{N}$ practice is a sustainable management practice that provides farmers the higher economic returns as well as lowers the risk of nutrient loss, it is important to understand the effects of timing and rate of $\mathrm{N}$ application on corn productivity and its economic return. There are very few studies, if any, that have investigated the effect of various in-season $\mathrm{N}$ management practices, including sidedressing and late season $\mathrm{N}$ application through central dribble irrigation, at varying $\mathrm{N}$ application rates during planting. Also, the investigation on the economic returns of various in-season $\mathrm{N}$ management practices by considering the uncertainties in price of variables influencing the economic return, such as corn yield, price for corn yield and fertilizers, and labor costs are limited. The objectives of this study were to

\section{a. Determine corn response to $\mathrm{N}$ fertilization rate and timing;}

b. Compare the economics of in-season $\mathrm{N}$ management practices with the current (i.e., baseline) management practice that involves application of large quantities of $\mathrm{N}$ prior to planting and small portion at planting by examining the uncertainties associated with price of variables influencing the economic return of corn production.

\section{Methodology \\ Experimental setup}

A field-scale experiment was conducted in 2015 at the Molly Caren Farm near London (39.962 ${ }^{\circ} \mathrm{N}, 83.436{ }^{\circ} \mathrm{W}$ ), Ohio to examine the effect of both timing and $\mathrm{N}$ application rates on corn yield. The site has primarily been in a corn-soybean rotation with wheat every five years. In 2014, the field was planted in wheat. Field operations included conservation tillage and different $\mathrm{N}$ application times and rates. (Table 1) summarizes the $\mathrm{N}$ application times, methods, fertilizer types, and rates used in the experiment. A corn hybrid (LG2620) was planted at a row spacing of $0.76 \mathrm{~m}$ with a seed population of 81.2 thousand seeds per hectare (i.e., $32.86 \mathrm{ksds}$ acre-1). Nitrogen serve (i.e., $2.34 \mathrm{~kg} /$ ha) was added during pre-planting to inhibit potential loss of $\mathrm{N}$ through nitrification of applied $\mathrm{N}$.

Table 1: Summary of $\mathrm{N}$ applications.

\begin{tabular}{|c|c|c|c|}
\hline Application Timing & Application Method & Fertilizer Type & Rate(kg ha-1) \\
\hline Pre-planting (April 13) & 8 inch depth with banding & Anhydrous Ammonia & 179 \\
\hline \multirow{2}{*}{ At-planting (May 9) } & 2 inches beside and 2 inches below seeds & Liquid (18-18-0)* & 0,34, or 67 \\
\cline { 2 - 4 } & In-furrow with the seed & Pop-up (10-34-0) & 11 \\
\hline Mid-season (June 11) & Side-dressing & UAN 28\% & 44 \\
\hline Late-season (July 7) & Central dribble irrigation & UAN 28\% & 49 \\
\hline
\end{tabular}

Note: *18-18-0 fertilizer include 1:1 ratio of $10-34-0$ and UAN $28 \%$ fertilizers

Table 2: Summary of $\mathrm{N}$ application treatments.

\begin{tabular}{|c|c|c|}
\hline Treatment & Total N(kg/ha) & Nitrogen Application Timing \\
\hline A $(10+0)$ & 45 & 78 \\
\hline A $(10+30)$ & 190 & At-planting \\
\hline A70 (10+60) & 224 & Pre-planting and at-planting \\
\hline PA $(10+0)$ & 258 & \\
\hline
\end{tabular}


Agricultural Research \& Technology: Open Access Journal

\begin{tabular}{|c|c|c|}
\hline PAM10 $(10+0)$ & 235 & \multirow{3}{*}{ Pre-planting, at-planting, and mid-season } \\
\hline PAM40 (10+30) & 269 & \\
\hline PAM70 $(10+60)$ & 302 & \\
\hline PAL10 $(10+0)$ & 240 & \multirow{3}{*}{ Pre-planting, at-planting, and late-season } \\
\hline PAL40 $(10+30)$ & 273 & \\
\hline PAL70 $(10+60)$ & 307 & \\
\hline PAML10 $(10+0)$ & 284 & \multirow{3}{*}{$\begin{array}{l}\text { Pre-planting, at-planting, mid-season, and } \\
\text { late-season }\end{array}$} \\
\hline PAML40 $(10+30)$ & 318 & \\
\hline PAML70 $(10+60)$ & 352 & \\
\hline AM10 (10+0) & 56 & \multirow{3}{*}{ At-planting and mid-season } \\
\hline AM40 (10+30) & 90 & \\
\hline AM70 $(10+60)$ & 123 & \\
\hline AL10 $(10+0)$ & 60 & \multirow{3}{*}{ At-planting and late-season } \\
\hline AL40 $(10+30)$ & 94 & \\
\hline $\operatorname{AL70}(10+60)$ & 128 & \\
\hline AML10 $(10+0)$ & 105 & \multirow{3}{*}{ At-planting, mid-season, and late season } \\
\hline AML40 $(10+30)$ & 139 & \\
\hline AML70 $(10+60)$ & 172 & \\
\hline Baseline $(0+40)$ & 224 & Pre-planting and at-planting \\
\hline
\end{tabular}

Note: 10 or 0 in the first part of the parentheses indicates the amount of pop-up N fertilizer (in Ibs/acre) and 0,30,60 and 40 in the second part of the parentheses indicate the amount of $2 X 2$ fertilizer (in lb/acre) used in the planting.

A total of $24 \mathrm{~N}$ treatments were evaluated using combinations of four $\mathrm{N}$ application times and three planter $\mathrm{N}$ rates against the baseline treatment as summarized in (Table 2). Except for the treatment with $\mathrm{N}$ applied only at-planting, all other treatments received two or more $\mathrm{N}$ applications (Table 2). For example, A10 treatment received $11 \mathrm{~kg} \mathrm{~N}^{-1}$ at planting; AM40 treatment received $45 \mathrm{~kg} \mathrm{~N} \mathrm{ha}^{-1}$ at planting and $45 \mathrm{~kg} \mathrm{~N} \mathrm{ha}^{-1}$ for side-dressing; PAML treatment received four $\mathrm{N}$ applications: pre-planting, atplanting, mid-season, and late-season. The study was conducted on a 9.67ha field, and treatments were established using a block design, with individual blocks ranging from 0.20 to 0.60 ha in size.

Each block was $12.2 \mathrm{~m}$ wide with length varying between 152 to $202 \mathrm{~m}$. There were eight blocks representing the timing treatments, and each block was divided into five segments with three $\mathrm{N}$ application rates $\left(11,45\right.$, or $\left.78 \mathrm{~kg} \mathrm{~N} \mathrm{ha}^{-1}\right)$ at-planting. One segment received $11 \mathrm{~kg} \mathrm{~N} \mathrm{ha}^{-1}$, two segments received $45 \mathrm{~kg} \mathrm{~N} \mathrm{ha}^{-1}$ and the remaining two segments received $78 \mathrm{~kg} \mathrm{~N} \mathrm{ha}^{-1}$. In blocks representing the timing treatment, there were two replicates (i.e., in the form of stripes) for each of the three planter $\mathrm{N}$ rates. Within each replicate, there was a single pass of the planter and two pass of the 8-row harvester. There was also a baseline treatment that received $179 \mathrm{~kg} \mathrm{~N}^{-1}$ prior to planting and $45 \mathrm{~kg}$ $\mathrm{N} \mathrm{ha}^{-1}$ at planting. The baseline treatment was carried in between the eight timing treatment blocks.

Corn was harvested with a moisture content of $\sim 18 \%$ on 14 September 2015 using a John Deere S660 (John Deere, Moline, IL, USA) equipped with a Precision Planting Yield Sense monitor in the same direction. The combine header cut width (i.e., swath) was set to $6 \mathrm{~m}$ and the distance traveled between logged data points was $2 \mathrm{~m}$. The yield monitor was calibrated twice before and during the harvest to obtain accurate yield estimates. As the grain was harvested, the weight of each load was estimated by the yield monitor. That specific load was then offloaded from the combine hopper and weighed using a certified scale. The actual weight was then entered into the yield monitor to post calibrate the system. Further, yield data near the corner of each treatment were discarded from the analyses because the yield monitor data typically has some errors when a harvester makes a turn at the corner of a field [10]. Corn yield data from the study area were processed using the Spatial Management System Basic software.

\section{Economic Analyses}

Economic return from each treatment was estimated as the difference between the costs related to fertilization and the mean yield gross return. Costs related to fertilization included the costs of fertilizer and its application, i.e., labor and machinery costs (Table 3). For this study, the fertilization costs varied across the treatments, while the other costs related to corn production were assumed to be constant. Because there exists high interannual and spatial variability in the price of these variables across regions and growing season [11-13] uncertainty analysis was conducted to account for their impacts on the economic returns of various $\mathrm{N}$ treatments. For this purpose, average price of fertilizers, including Anhydrous Ammonia, 10-34-0 and UAN $28 \%$, and corn price from 2015-2016 were considered. Labor and machinery costs for $\mathrm{N}$ application were based on a survey of 183 Iowa farmers, custom operators, and farm managers [11]. Monte Carlo simulations $(10,000$ trials) were conducted to analyze the 
associated uncertainties. In addition to the economic parameters used for simulations, yield data from various $\mathrm{N}$ treatments were Table 3: Cost of fertilizer and its application.

\begin{tabular}{|c|c|c|c|}
\hline \multicolumn{4}{|c|}{ Fertilizer Cost ( $\$ / \mathrm{kg}$ of Fertilizer) } \\
\hline Fertilizer Type & \$ per kg (Mean) & $\begin{array}{l}\text { Probability Distributions, and Statistics of } \\
\text { Parameters used for Monte Carlo Simulation }\end{array}$ & Source \\
\hline \multirow[t]{2}{*}{ Anhydrous Ammonia } & $\$ 0.12$ & Normal Distribution & (Quinn 2016) \\
\hline & & (Standard Deviation:0.025) & \\
\hline \multirow[t]{2}{*}{$10-34-0$} & $\$ 0.12$ & Normal Distribution & (Quinn 2016) \\
\hline & & (Standard Deviation:0.013) & \\
\hline \multirow[t]{2}{*}{ UAN $28 \%$} & $\$ 0.06$ & Normal Distribution & (Quinn 2016) \\
\hline & & (Standard Deviation:0.011) & \\
\hline \multirow[t]{2}{*}{ N-Serve } & $\$ 12.29 /$ ha & Triangular Distribution & Expert Opinion* \\
\hline & & $( \pm 10 \%$ of the average) & \\
\hline \multicolumn{4}{|c|}{ Labor and machinery costs involved in fertilization $\$ /$ ha } \\
\hline \multirow[t]{2}{*}{ Anhydrous Ammonia } & $\$ 30.26$ & Triangular Distribution & (Plastina et al. 2016) \\
\hline & & (Range: $\$ 17.29-49.40$ ) & \\
\hline \multirow[t]{2}{*}{ Side-dressing } & $\$ 27.54$ & Triangular Distribution & (Plastina et al. 2016) \\
\hline & & (Range: $\$ 14.82-37.05$ ) & \\
\hline \multirow[t]{2}{*}{ Late Season } & $\$ 19.76$ & Triangular Distribution & Expert Opinion* \\
\hline & & (Range: $\$ 9.88$ - 29.64) & \\
\hline \multicolumn{4}{|c|}{ Corn Price (\$/bushel) } \\
\hline \multirow[t]{2}{*}{ Corn Price } & $\$ 3.54$ & Normal Distribution & $\begin{array}{l}\text { (Iowa State University Extension } \\
\text { 2017) }\end{array}$ \\
\hline & & (Standard Deviation: 0.22) & \\
\hline
\end{tabular}

Note: *Farmers and extension specialists in the state were consulted. Cost of $\$ 1,108 /$ ha was considered to account the cost involved in seed, chemical, machinery and equipment use.It remained same across the treatments.

Table 4: Corn grain yield by $\mathrm{N}$ timing and rate treatments.

\begin{tabular}{|c|c|c|c|c|c|c|}
\hline \multirow[b]{3}{*}{ Timing Treatment } & \multicolumn{3}{|c|}{ Corn Yield (ton/ha) } & \multicolumn{3}{|c|}{ Standard Deviation (ton/ha) } \\
\hline & \multicolumn{3}{|c|}{ Planter N Rates (kg/ha) } & \multicolumn{3}{|c|}{ Planter N Rates (kg/ha) } \\
\hline & 11 & 45 & 78 & 10 & 40 & 70 \\
\hline A & 8.8 & 10.6 & 13.5 & 1.5 & 1.9 & 2 \\
\hline $\mathrm{AL}$ & 11.8 & 13.3 & 15.2 & 1.2 & 1.7 & 1.3 \\
\hline $\mathrm{AM}$ & 11.9 & 13.8 & 15.1 & 1.7 & 1.8 & 1.7 \\
\hline AML & 14.7 & 14.9 & 15.4 & 1.2 & 1.5 & 1.2 \\
\hline PA & 15.5 & 15.8 & 15.6 & 2 & 1.7 & 2 \\
\hline PAL & 15 & 15.4 & 14.9 & 1.7 & 1.4 & 1.2 \\
\hline PAM & 15.2 & 16.1 & 16 & 1.2 & 1.1 & 1.4 \\
\hline PAML & 16.4 & 15.8 & 16.5 & 1.3 & 1.4 & 1.3 \\
\hline Baseline & \multicolumn{3}{|c|}{15.2} & \multicolumn{3}{|c|}{1.9} \\
\hline
\end{tabular}

\section{Statistical Analyses}

Corn yields from various $\mathrm{N}$ treatments were analyzed using both one-way and two-way ANOVA. One-way ANOVA with Tukey test was conducted to examine whether there were any significant differences in means of corn yields between eight $\mathrm{N}$ timing treatments at three planter $\mathrm{N}$ rates and the baseline treatment. Because the treatments plots were uneven in size, assumed to have normal distributions, characterized with means and standard deviations (Table 4 in the result section). 
models as it provided the highest $\mathrm{R}^{2}$ and lower residuals. In models with plateaus, maximum yield occurs at the plateau.

\section{Results and Discussion}

\section{Corn yield response to nitrogen application timing and rate}

Two-way ANOVA showed a significant influence of $\mathrm{N}$ application timing, $\mathrm{N}$ rate at planting, and their interactions on corn yield. The average corn yield was highest for the treatment PAML that received the maximum amount of $\mathrm{N}$ fertilizer, and was lowest for the treatment A that received the least amount of fertilizer (i.e., only at planting). There was high variability in corn yield in treatment A followed by AM, AL and PA, which could be attributed to varying degree of $\mathrm{N}$ stress in these treatments. The amount of $\mathrm{N}$ application at planting was found to have a significant impact on corn yield of the treatments that were unfertilized prior to planting such as A, AL, AM and AML. A high degree of $\mathrm{N}$ stress due to application of lower amounts of $\mathrm{N}$ is likely to lower corn yields in these treatments. With an increase in the $\mathrm{N}$ application rate (i.e., from 11 to $78 \mathrm{~kg} \mathrm{ha}^{-1}$ ) at planting, corn yields were found to increase significantly $(p<0.05)$ (Table 4). For the treatments that received $N$ prior to planting (i.e., PA, PAL, PAM and PAML), corn yield did not increase significantly ( $p>0.05$ ) with an increased $\mathrm{N}$ rate at planting (Figure 1a).

Pairwise comparisons of corn yields indicated that, with lower $\mathrm{N}$ application at planting, the differences in corn yields between baseline and other $\mathrm{N}$ timing treatments increased significantly $(\mathrm{p}<0.05)$. However, with higher $\mathrm{N}$ application at planting, there were minimum yield differences among $\mathrm{N}$ timing treatments (Figure 1b). For example, when $11 \mathrm{~kg} \mathrm{~N} / \mathrm{ha}$ was applied at planting, there were significant differences in corn yield among treatments such as baseline, AL, AM and PA. But, with the application of $78 \mathrm{~kg} \mathrm{~N} /$ ha at planting, there were minimum differences in corn yield among the same treatments. The percent differences in average corn yield from various treatments relative to the baseline ranged between -42 to $8 \%,-30$ to $6 \%$, and -11 to $9 \%$ with $\mathrm{N}$ application of 11,45 , and $78 \mathrm{~kg} \mathrm{~N} / \mathrm{ha}$ at planting, respectively. Additionally, unlike treatments receiving zero $\mathrm{N}$ prior to planting, for most of the treatments receiving $\mathrm{N}$ prior to planting, such as PA, PAL and PAML, the differences in corn yield were insignificant. There were significant differences $(\mathrm{p}<0.05)$ in corn yield between treatments A10, A40 and A70, but the difference in corn yield between treatments such as PAML10, PAML40 and PAML70 were minimum and insignificant.

In some $\mathrm{N}$ treatment plots, the lack of adequate $\mathrm{N}$ early in the growing season resulted in yield loss that was regained with additional N application during V7 and V11 stages (Figure 2). This was apparent in the yield response curve of the treatments that received $11 \mathrm{~kg} \mathrm{~N} / \mathrm{ha}$ at planting. The in-season economic optimum $\mathrm{N}$ rates were 160,148 and $95 \mathrm{~kg} \mathrm{ha}^{-1}$ for treatment plots receiving 11, 45 and $78 \mathrm{~kg} \mathrm{ha}^{-1} \mathrm{~N}$ at planting, respectively (Table 5). This optimum $\mathrm{N}$ rate is lower than the $\mathrm{N}$ application in the baseline treatment. This suggests that in-season $\mathrm{N}$ application has potential to avoid $\mathrm{N}$ related yield loss with lower use of $\mathrm{N}$ than the baseline.

Table 5: Quadratic-Plateau fit function for corn grain yield as a function of $\mathrm{N}$.

\begin{tabular}{|c|c|c|c|}
\hline & \multicolumn{3}{|c|}{ Planter N Pass } \\
\hline Parameters & $\mathbf{1 1}$ & $\mathbf{4 5}$ & $\mathbf{7 8}$ \\
\hline a & 7.67 & 9.55 & 12 \\
\hline b & 0.08 & 0.06 & $0.0416 \mathrm{NS}$ \\
\hline c & 0 & 0 & $-0.0002 \mathrm{NS}$ \\
\hline R2 & 0.93 & 0.95 & 0.61 \\
\hline Critical N(kg/ha) & 160 & 148 & 95 \\
\hline
\end{tabular}

Note: NS- not significant at $p<0.05$.
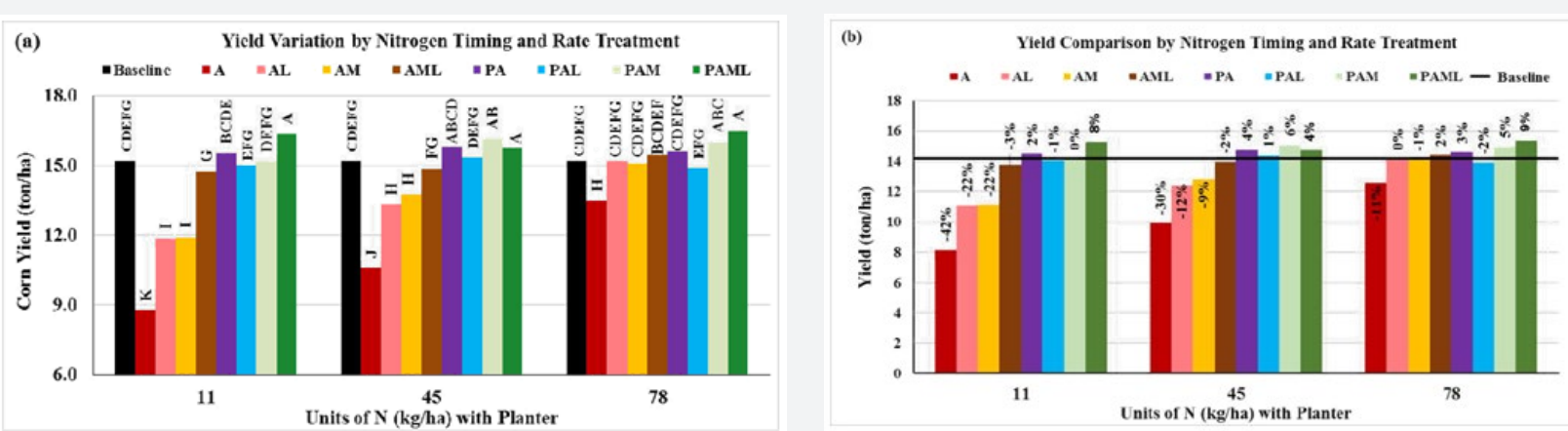

Figure 1: Mean corn grain yield for baseline and eight $\mathrm{N}$ timing treatments at three planter $\mathrm{N}$ rates. Within each treatment (a) bars that do not share a letter are statistically different at $p<0.05$, (b) percent difference in yield based on baseline average yield. 


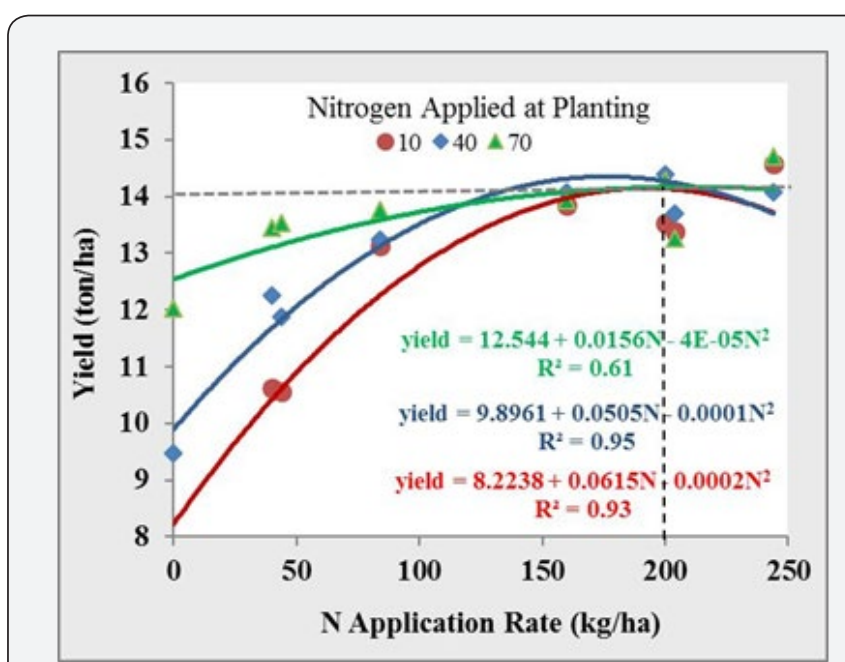

Figure 2: Quadratic-plateau fit of corn grain yield response to $\mathrm{N}$ application summarized based on three $\mathrm{N}$ application rates at planting. Critical $\mathrm{N}$ indicates the $\mathrm{N}$ rate after which corn yield response either plateaus or declines. Dashed horizontal and vertical lines indicate the yield and $\mathrm{N}$ fertilizer use in the baseline treatment.

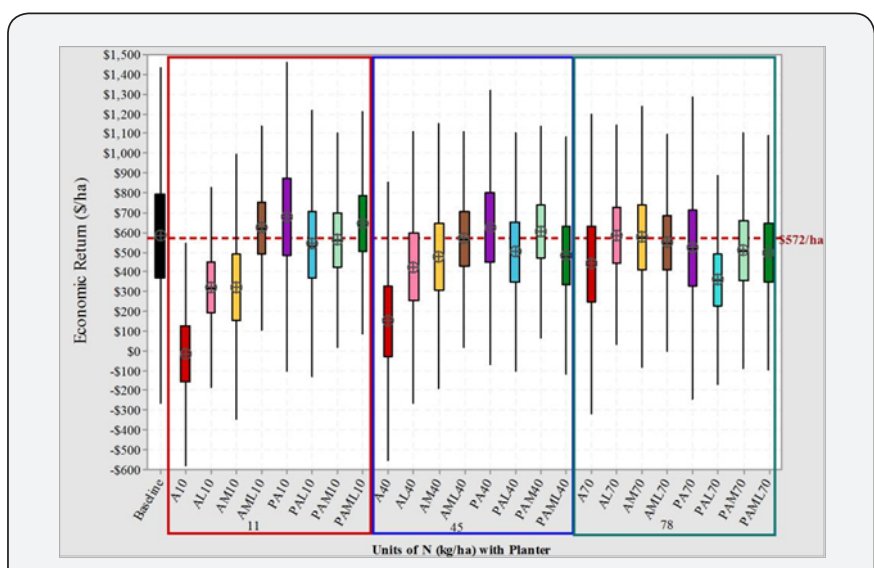

Figure 3: Profit comparison by nitrogen fertilization timing and rate. Timing treatments are organized by units of $\mathrm{N}(\mathrm{kg} / \mathrm{ha})$ with planter. Red dashed line indicates net profit under the baseline treatment. Boxplots show the distribution of economic returns.

\section{Economic return analyses}

Economic return analyses based on Monte Carlo simulations suggested that net profit of corn production in various $\mathrm{N}$ treatments varied considerably, and was related mainly to corn yield and the $\mathrm{N}$ fertilizer application rate at planting. Unlike treatments that received $\mathrm{N}$ application prior to planting, treatments that received zero $\mathrm{N}$ application prior to planting were found to yield higher economic return due to in-season $\mathrm{N}$ applications with higher $\mathrm{N}$ at planting. For example, with at planting application of $11 \mathrm{~kg} \mathrm{~N} / \mathrm{ha}$, treatment PA had the highest mean economic return followed by PAML and AML. But with $78 \mathrm{~kg}$ $\mathrm{N} /$ ha at planting, the economic returns of treatments such as $\mathrm{AL}$, AM and AML was found to be higher than PA, PAL, PAM and PAML
(Figure 3). Also, the treatments such as AM70, AL70 and AML10 that received only in-season $\mathrm{N}$ applications were found to yield higher mean economic returns than the baseline, and returns were higher by $\$ 1.37 / \mathrm{ha}$, $\$ 11 / \mathrm{ha}$ and $\$ 47 / \mathrm{ha}$, respectively.

Although in-season $\mathrm{N}$ application helped recover $\mathrm{N}$ stress related yield loss to some extent in treatments such as A, AM, $\mathrm{AL}$ and AML, yields in these treatments were significantly lower than the baseline treatment, and resulted in comparatively lower economic returns. However, in treatments receiving $\mathrm{N}$ prior to planting, application of in-season $\mathrm{N}$ corn yield was not significantly different from the baseline. Use of in-season $\mathrm{N}$ application was thus an additional cost to these treatments that reduced the economic returns of them compared to the baseline. For example, although the treatments such as PAML70, PAM70 and PA70 had higher corn yield than the baseline treatment, the increased yield did not cover the additional fertilizer costs.

It is also important to notice that although the mean economic returns of various treatments involving in-season $\mathrm{N}$ application such as AL40, AM40, AML40, A70, AL70, AM70 and AML70 were less than the baseline, the range of economic returns from these treatments coincided with the range of economic benefit from the baseline treatment. This suggests that in-season $\mathrm{N}$ treatments can provide higher or equivalent economic return than the baseline or the treatments with prior $\mathrm{N}$ application. Additionally, findings of this study suggest that higher application of $\mathrm{N}$ does not always result in higher yield and economic returns.

\section{Summary and Conclusion}

The results from this study demonstrated that the $\mathrm{N}$ management practices involving in-season fertilizer applications with zero $\mathrm{N}$ application prior to planting have the potential to perform better in terms of both crop productivity and economic returns than the $\mathrm{N}$ management practices that involve $\mathrm{N}$ application prior to planting. The study observed the lowest yield and economic return from treatment $\mathrm{A}$ that received $\mathrm{N}$ only at planting. Unlike treatments receiving zero $\mathrm{N}$ application prior to planting, treatments receiving $\mathrm{N}$ application prior to planting did not show significant increase in yield and economic returns with the application of in-season N. Treatments such as AML10, AL70 and AM70 were found to have higher economic returns than the baseline and other $\mathrm{N}$ treatments. Although the uncertainty analyses based on Monte Carlo simulation suggested that the inseason $\mathrm{N}$ application can perform better than the baseline, the findings should be used with caution as these results only reflect the performance of certain fertilizer strategies on corn yields of one field. Additionally, variabilities in labor costs and price for corn and fertilizers were based on only two years of data (i.e., 2015-2016). Additional experiments are needed to test similar strategies for more fields and years. Although preliminary, findings of this study suggest that corn yield can be improved by adopting in-season $\mathrm{N}$ application practices rather than the practices that focus on $\mathrm{N}$ application prior to planting. 


\section{Acknowledgement}

This material is based upon the project supported by the Field to Faucet program under the College of Food, Agricultural, and Environmental Science at the Ohio State University under Grants No. F2F-000004. The authors thank Mrs. Mary Wicks (Department of Food, Agricultural and Biological Engineering, OSU) for her critical editorial and technical review.

\section{References}

1. Donner SD, Kucharik CJ (2008) Corn-based ethanol production compromises goal of reducing nitrogen export by the Mississippi River Proceedings of the National Academy of Sciences 105(11): 4513-4518.

2. Zhang $X$, Davidson EA, Mauzerall DL, Searchinger TD, Dumas $P$, et al. (2015) Managing nitrogen for sustainable development. Nature 528(7580): 51-59.

3. Zillén L, Conley DJ, Andrén T, Andrén E, Björck S (2008) Past occurrences of hypoxia in the Baltic Sea and the role of climate variability, environmental change and human impact. Earth-Science Reviews 91(1): 77-92.

4. Huang W (2009) Factors contributing to the recent increase in US fertilizer prices. DIANE Publishing.

5. Cassman KG, Dobermann A, Walters DT (2002) Agroecosystems, Nitrogen-use Efficiency, and Nitrogen Management. AMBIO 31(2): 132-140.

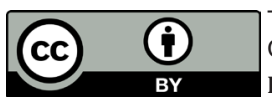

This work is licensed under Creative Commons Attribution 4.0 License DOI: 10.19080/ARTOAJ.2017.04.555660
6. Scharf PC, Wiebold WJ, Lory JA (2002) Corn yield response to nitrogen fertilizer timing and deficiency level. Agronomy Journal 94(3): 435441.

7. Ritchie SW, Hanway JJ, Benson GO (1993) How a corn plant develops.

8. Binder DL, Sander DH, Walters DT (2000) Maize response to time of nitrogen application as affected by level of nitrogen deficiency. Agronomy Journal 92(6): 1228-1236.

9. Sawyer JE, Lundvall JP, Hawkins JA (2007) In-season Nitrogen management for corn production. North Central Extension-Industry Soil Fertility Conference.

10. Lyle G, Bryan BA, Ostendorf B (2014) Post-processing methods to eliminate erroneous grain yield measurements: review and directions for future development. Precision agriculture 15(4): 377-402.

11. Plastina A, Johanns A, Erwin J (2016) 2016 Iowa Farm Custom Rate Survey.

12. Quinn R (2016) DTN Retail Fertilizer Trends.

13. Schnitkey G (2016) Averages and Seasonality of Prices for Nitrogen Fertilizers. Nitrogen, sustainable agriculture and food security. A review. Agronomy for Sustainable Development 30(1): 43-55.

\section{Your next submission with Juniper Publishers will reach you the below assets}

- Quality Editorial service

- Swift Peer Review

- Reprints availability

- E-prints Service

- Manuscript Podcast for convenient understanding

- Global attainment for your research

- Manuscript accessibility in different formats

( Pdf, E-pub, Full Text, Audio)

- Unceasing customer service

Track the below URL for one-step submission https://juniperpublishers.com/online-submission.php 